\title{
AS QUINAS DE MENSAGEM E A “ÍNCLITA GERAÇÃO” EM OS LUSÍADAS
}

Sonia Mara Ruiz Brown ${ }^{1}$

RESUMO: Este estudo busca revelar as aproximações existentes entre Os Lusíadas e Mensagem por meio da imagem heráldica de "As Quinas", comparando e analisando a maneira como Pessoa e Camões abordaram as personagens históricas, os infantes da "ínclita geração", cada um em seu momento histórico.

PALAVRAS-CHAVE: Camões, Fernando Pessoa, Os Lusíadas, Mensagem, As Quinas

ABSTRACT: This essay attempts to show the relationship between Os Lusíadas and Mensagem by means of the heraldic image in "As Quinas", by comparing and analyzing the approach Pessoa and Camões have towards the historic characters, the royal infants of the "ínclita geração", each in their historic moment.

KEY-WORDS: Camões, Fernando Pessoa, Os Lusíadas, Mensagem, “As Quinas”

\author{
"Cessa o teu canto! \\ Cessa, que, enquanto \\ O ouvi, ouvia \\ Uma outra voz \\ Como que vindo \\ Nos interstícios \\ Do brando encanto \\ Com que o teu canto \\ Vinha até nós."
}

Fernando Pessoa

\section{Introdução}

Tanto em Bakhtin quanto em T. S. Eliot temos a afirmação de que nenhum discurso é auto-suficiente, tanto no sentido imanente quanto no literal. Bakhtin, nos seus estudos, focalizou a língua em seu uso real e definiu-a como dialógica ("um enunciado deve ser considerado antes de tudo como resposta a enunciados anteriores de uma esfera dada [...] ele refuta, os confirma, os completa" (BAKHTIN, 1992, p. 298), entendendo que para o enunciador construir seu discurso, levará em conta o discurso de outrem, que está presente no seu. T. S. Eliot priorizou a linguagem artística e o diálogo existente entre as obras literárias, ressaltando que "nenhum poeta, nenhum artista tem sua

\footnotetext{
${ }^{1}$ Doutoranda em Literatura Portuguesa na FFLCH/USP, sob a orientação da Prof. Doutora Maria Helena Nery Garcez.
} 
significação completa sozinho. Seu significado e a apreciação que dele fazemos constituem a apreciação de sua relação com os poetas e artistas mortos" (ELIOT, 1989, p. 39).

Do ponto de vista filosófico, Luigi Pareyson, o filósofo da estética, expõe que o inovar e conservar são funções artísticas inseparáveis, pois "continuar sem inovar significa apenas copiar e repetir, e inovar sem continuar significa fantasiar no vazio, sem fundamento" (PAREYSON, 2001, p. 137).

Sob essas perspectivas e ainda com o aval do próprio Fernando Pessoa, na epígrafe acima é que estaremos enfocando, da primeira parte ("Brasão") de Mensagem, de Fernando Pessoa ${ }^{2}$, a terceira do "Brasão", isto é, "As Quinas", e as personagens históricas aí citadas (D. Duarte, D. Fernando, D. Pedro, D. João e D. Sebastião) em $O s$ Lusíadas, de Camões, aproximando-os para analisar o que pôde servir de desafio ou estímulo.

Pessoa e Camões propuseram-se a narrar e a interpretar a história de um dado período de Portugal, sob o ponto de vista da época em que viveram, da sociedade que os circundava e os influenciava, do próprio eu-poético e de suas respectivas idiossincrasias. O estudo comparado das épicas pessoana e camoniana legitima-se, cremos, sobretudo por dois pontos.

O primeiro deles é o paralelo entre o percurso existencial de Camões e Pessoa. Embora em épocas distintas, ambos viveram períodos conturbados da história portuguesa, se ausentaram da pátria e conheceram a mesma região. Pessoa viveu dos sete aos dezessete anos em Durban, na África do Sul, e Camões esteve durante aproximadamente dois anos no Oriente, cumprindo pena de prisão e prestando serviço militar, em seguida, outro período viajando de Goa a Moçambique. Conheceram, portanto, a mesma região, pois o porto de Durban fica próximo ao Cabo da Boa Esperança, local onde ocorreu a maior proeza portuguesa da história.

O segundo ponto que nos leva a compará-los é a própria declaração de Pessoa, supostamente referindo-se a si próprio, quanto ao "aparecimento de poeta supremo da nossa raça", "o poeta de todos os tempos" e "o supra-Camões da nossa terra" (PESSOA, 1978, p. 367). Pessoa prognostica que, fatalmente, surgirá um Grande Poeta que

\footnotetext{
${ }^{2}$ A primeira parte de Mensagem aborda as origens de Portugal e chega até o início da expansão marítima. 3 “As Quinas" representam a essência do espírito português, religioso e cristão desde a origem.
} 
deslocará para o segundo plano a figura consagrada de Camões. Em outro artigo expressivamente intitulado "Reincidindo", também publicado em A Águia, Pessoa propõe-se a esclarecer o supra-Camões e suas alegorias, referindo-se a um terceiro período literário que estaria por ocorrer e seria uma das "magnas épocas literárias", profetizando que Portugal "se prepara para o ressurgimento assombroso, um período de criação literária e social como poucos o mundo tem visto". (CRESPO, 1988, p. 27-28)

Embora Pessoa não tenha tratado a obra camoniana, o anúncio do supra-Camões legitima o nosso estudo comparativo. Ao reinventar o discurso épico no século XX, Pessoa chegaria à altura do grande vate português?

Os Lusíadas e Mensagem são marcos da literatura portuguesa e da literatura em língua portuguesa, e Mensagem dialoga, por meio do gênero poético, com Os Lusíadas.

A razão deste nosso trabalho é exatamente a discussão desse diálogo, a partir de uma das partes da Mensagem, "As Quinas”, por meio da comparação e da análise da maneira como cada um deles abordou e interpretou as mesmas personagens históricas.

Transcrevemos abaixo o poema "As Quinas” e a estância em Os Lusíadas que faz referência à mesma personagem histórica apresentada em Mensagem. Os poemas, então, serão discutidos nesta ordem e, depois, comparados.

\section{Estudo dos Poemas}

"As Quinas":

D. Duarte, Rei de Portugal

Meu dever fez-me, como Deus ao mundo.

A regra de ser Rei almou meu ser,

Em dia e letra escrupuloso e fundo.

Firme em minha tristeza, tal vivi.

Cumpri contra o Destino o meu dever.

Inutilmente? Não, porque o cumpri.

\section{Os Lusíadas:}

Canto V, estância LI e primeiros versos da LII

Não foi do rei Duarte tam ditoso.

O tempo que ficou na summa alteza;

Que assim vai alternando o tempo iroso

O bem co'o mal, o gosto co'a tristeza.

Quem viu sempre um estado deleitoso?

Ou quem viu em fortuna haver firmeza?

Pois inda neste reino e neste rei

Não usou ella d'esta lei?

Viu ser captivo o sancto irmão Fernando

Que a tão altas empresas aspirava. (...) 
Detendo-nos primeiramente na forma, observamos regularidade no metro dos dois poemas, cujos versos são todos decassílabos heroicos, com exceção do terceiro verso do poema "D. Duarte, Rei de Portugal”, que também é decassílabo, mas sáfico. A rima também é regular: alternada no poema pessoano ( $\mathrm{aba} / \mathrm{cbc}$ ) e, no poema de Camões, estrofação em oitava-rima (abababcc), ou seja, rima cruzada em seis versos e emparelhada em dois.

Embora, neste momento, os dois poemas sejam, quanto à forma, regulares, há que se observar que os versos de Os Lusíadas são sempre regulares no decorrer de 8816 versos em 1102 estrofes, quanto à rima e quanto à métrica, enquanto Mensagem "é uma verdadeira polifonia multifacetada em face do andamento uniforme da epopeia camoniana" (MOISÉS, 1996, p. 58).

No poema do poeta de Pessoa, que exige uma interpretação mais hermética, só se é sabido que se refere a D. Duarte pelo título (assim como em todos demais poemas de "As Quinas"). Uma vez, no entanto, assim compreendido, sabe-se ser ele o protagonista do poema, pois, historicamente, é conhecido o sofrimento de D. Duarte por não poder pagar o penhor da promessa de Ceuta, cuja garantia era D. Fernando, seu irmão mais novo, prisioneiro em Tanger e ali cativo até o fim da vida.

Declara na sua própria $\mathrm{voz}^{4}$ : "Meu dever fez-me" e se compara a Deus no cumprimento de seu dever perante o mundo. No verso seguinte ("A regra de ser Rei, almou meu ser,"), a paronomásia (ser (substantivo) / ser (verbo)) estabelece definitivamente o que deve ser cumprido; a opção pelo verbo almar intensifica e aprofunda o dever, a regra na personalidade real, que não se limitou ao seu entendimento, à materialidade do corpo, mas invadiu sua unidade e sua inteireza vitais, sua consciência pensante em sua dimensão psicológica e orgânica. Sob o mesmo prisma, pode-se acrescentar que o verbo é um neologismo cuja escolha pode ser justificada através das palavras de Ibañez Langlois:

é lei geral da poesia o resgatar a palavra de seu emprego quotidiano passageiro e prático - para erigi-la em objeto substantivo, que leva consigo sua própria realidade, porque "solidifica" a experiência que

\footnotetext{
${ }^{4}$ Em "Os Castelos", defesa externa de Portugal, é necessária a intervenção de um mediador, dirigindo-se a um interlocutor variável, que é a figura referida no título de cada poema; em "As Quinas", ocorre a voz da figura histórica anunciada no título, que expõe o seu monólogo.
} 
designa, redime a palavra de uma mera condição de signo ou meio. (LANGLOIS, 1964, p. 65)

O verso subsequente do poema ("Em dia e letra escrupuloso e fundo"), único decassílabo sáfico no texto, rompe com o ritmo harmonioso e solene dos versos heróicos anteriores. Esse rompimento se mostra como exceção proposital para mudança de ênfase, introduzindo elementos concretos (“Em dia e letra ....”) em contraposição ao 'sentir' heroico que vinha marcando o texto. Mesmo assim, permanecem no concreto sentimentos demarcados pela exigência e pelo rigor ("escrupuloso") e pela intensidade ("fundo").

Continua o eu-poético numa expressiva metonímia: "Firme em minha tristeza, tal vivi”, já que viveu firme, sem titubear com decisão tomada de não beneficiar o irmão, o que lhe gerou tristeza constante. Nesse verso e nos seguintes, a sonoridade da vogal /i/ se faz sentir intensamente ("Firme... minha tristeza, vivi / Cumpri... Destino.../ Inutilmente? ... cumpri) e marca a profundidade, a agudeza do penetrar, no ser real, da resolução assumida e a dor que dela advém. Esse mesmo sentimento é ainda demarcado pela presença do verbo cumprir no início do quinto verso e no final do sexto, sugerindo o iniciar e o terminar de uma mesma determinação. Na forma verbal cumpri repetida, ainda se pode destacar a sonoridade do /u/, corroborando com a do /i/ e, cremos, acrescentando a sensação de continuidade, de algo que permanece durante muito tempo.

Num questionamento retórico, o eu-poético pergunta: “Inutilmente?”. E responde: "Não. Porque o cumpri". O pronome oblíquo $o$, retoma o objeto direto do verso anterior, "o meu dever". O poema que, no seu primeiro verso, é iniciado pelo sujeito "Meu dever", termina com a forma verbal "cumpri" que traz proclítico o pronome $o$ (= "o meu dever"), marcando, com toda a ênfase e arte, a tristeza do agir pela vontade de cumprir o dever sem prazer, sem recompensa afetiva.

Na estância LI e nos dois primeiros versos da estância LII, do Canto IV de $O s$ Lusíadas, Camões, em estilo grandiloquente, mas muito perto da realidade, como que dela emergindo, enfoca D. Duarte na voz de Gama. 
Inicia a estrofe LI, afirmando sua não felicidade na posição real ${ }^{5}$ e a justifica através de antíteses (“O bem co’o mal, o gosto co'a tristeza”). Questiona, então: “Quem viu em fortuna haver firmeza?/ pois inda neste reino e neste rei/ Não usou Ella tanto d'esta lei?", expondo princípios muitas vezes presentes na obra camoniana: o da inconstância das coisas, o da mudança heracliana. Não há firmeza na fortuna, pois nada permanece, tudo está sempre em mutação.

Enquanto Pessoa procura mostrar a constância de um sentimento de dever a ser cumprido, que toma todo o ser, Camões detém-se na questão da mudança: houve um tempo mais "ditoso" com D. João I, mas não permaneceu, porque tudo muda, tudo está em contínua transformação, sobretudo no reinado de D. Duarte que "usou (...) tanto d'esta lei?".

Nos dois primeiros versos da estância seguinte (LII), é citado o fato histórico ocorrido em Tânger: "Viu [D. Duarte] ser captivo o sancto irmão Fernando/ Que a tão altas empresas aspirava". Como disse Hernani Cidade, referindo-se a Os Lusíadas, "rarissimamente a realidade foi assim valorizada como substância de poema" (CIDADE, 1963, p. 325).

O verbo "ver" é privilegiado em Os Lusíadas ("viu claramente visto", "vista de lince", "E o vi claramente (e não presumo/ Que a vista me enganava) levantar-se", "pronto co'a vista", "viu ser captivo"), pois são a epopeia do conhecimento científico colhido por seu autor, com as experiências de soldado e marinheiro e com seu fecundo talento poético. É por isso que Gama afirma ter D. Duarte visto seu irmão cativo.

Segunda Quina

D. Fernando, infante de Portugal

Deu-me Deus o seu gládio, porque eu faça A sua santa guerra.

Sagrou-me seu em honra e em desgraça, As horas em que um frio vento passa Por sobre a fria terra.

Poz-me as mãos sobre os hombros e doirou-me A fronte com o olhar;
Canto IV- estâncias LII e LIII

Viu ser captivo o sancto irmão Fernando, Que a tão altas empresas aspirava, Que por salvar o povo miserando Cercado, ao Sarraceno s'entregava, Só por amor da pátria está passando A vida de senhora feita escrava Por não se dar por elle a forte Ceita Mais o publico bem que o seu respeita!

\footnotetext{
${ }^{5} \mathrm{O}$ reinado de D. Duarte durou apenas cinco anos e foi marcado pela peste e outras catástrofes, além do desastre de Tânger em 1437.
} 
E esta febre de Além, quer me consome,

E este querer grandeza são seu nome

Dentro de mim a vibrar.

E eu vou, e a luz do gládio erguido dá

Em minha face calma.

Cheio de Deus, não temo o que virá,

Pois venha o que vier, nunca será

Maior do que a minha alma.
Codro, porque o inimigo não vencesse,

Deixou antes vencer da morte a vida;

Regulo, porque se a patria não perdesse

Quis mais a liberdade ver perdida;

Este, porque se Hespanha não temesse,

Ao captiveiro eterno se convida!

Codro, nem Curcio, ouvidos por espanto

Nem os Décios leais fizeram tanto.

O poema de Pessoa, que se refere a D. Fernando, também apresenta regularidade quanto à forma. É constituído de três quintetos, cujos versos, quanto à métrica, se alternam entre decassílabos heroicos e hexassílabos $(10,6,10,10,6)$. As rimas seguem o mesmo esquema ( $a, b, a, a, b)$ em todas as estrofes. Os segundos e os quintos versos de cada estrofe, entretanto, apresentam rima e métrica diferentes. A regularidade faz-se presente também nos enjambements que ocorrem sempre entre o primeiro e o segundo versos de cada estrofe.

Novamente, podemos aliar a regularidade da forma à ideia do que foi determinado, isto é, D. Fernando agindo pela determinação divina.

O poema, na voz do próprio D. Fernando, o infante santo que morreu prisioneiro no norte da África, filho de D. João I e irmão de D. Pedro e D. Duarte, revela todo o misticismo de um ser tocado por Deus e designado para uma missão: a então chamada guerra santa contra os mouros.

A dedicação à vontade divina é completa, pois a guerra é d'Ele, para a Sua honra (“Sagrou-me seu”). Duas vezes o possessivo revela a reverência e submissão a Deus. Essa sagração, no entanto, se faz na honra e na desgraça, antítese que, pela proximidade de termos de sentido antagônico, acentua o que há de positivo e negativo em cada um deles ${ }^{6}$. A desgraça exposta nos versos subsequentes advém de "As horas em que um frio vento passa/ Por sobre a fria terra"). A repetição do adjetivo frio intensifica seu sentido, porque desacelera a leitura, sobretudo por se tratar de palavra que contém hiato. A

\footnotetext{
${ }^{6}$ À ideia de sagrar-se em honra e desgraça, podemos relacionar a terceira estrofe do poema "Segundo/ O das Quinas" em que Cristo, embora ungido com desgraça e vileza, foi elevado como filho unigênito:

"Foi com desgraça e com vileza

Que Deus ao Christo definiu:

Assim o oppoz à Natureza

E Filho o ungiu".
} 
presença constante de sons sibilantes (Deus, seu, faça, sua, santa, sagrou, seu, desgraça, às, horas, passa, sobre) sugere efeitos sensoriais da reverência e sujeição a Deus.

A segunda estrofe expõe a honra com que D. Fernando foi sagrado: "Poz-me as mãos sobre os hombros e doirou-me/ A fronte com o olhar;"'. No primeiro verso, ocorre a única rima preciosa (doirou-me/ consome/ nome) do poema (as demais são ricas e pobres), exatamente no momento em que nos é revelada sua maior honra; no segundo, o enjambement que perturba e estimula o leitor.

Nos dois versos seguintes, verificamos a presença da anáfora "É esta/ É este" que realça o jogo rítmico e dá-lhe uma linha sequencial. D. Fernando aí confessa ter "febre de Além", febre de transcendência, num desejo de grandeza, mas se a tem, advém da vontade divina ("são seu nome"). Se alguns historiadores apontam a desgraça do infante, que ficou por penhor em Tânger e cumpriu o cativeiro até o fim da vida, como consequência da ambição desmedida dos portugueses, Pessoa, ao colocar sua voz no poema, expõe-no apenas como cumpridor de um anseio transcendental.

$\mathrm{Na}$ estrofe final, o polissíndeto ("E eu vou, e a luz do gládio...”) no primeiro verso e a sonoridade nasal que ocorre a partir do segundo verso (em, minha, calma, não, temo, senha, nunca, maior, minha, alma) sobrepõem-se à ideia de calma, da aceitação incondicional da tarefa. A repetição do verbo vir (virá, venha, vier) reforça a confiança no futuro. O possessivo minha é repetido apenas uma vez, quando seu foi repetido três vezes. Ocorre porque "minha alma", a alma do infante não mais lhe pertence, mas, sim, é Deus que vibra nele ("Dentro de mim a vibrar”).

Na visão camoniana, D. Fernando foi fiel à Pátria, respeitou mais o bem público de todos os portugueses que o seu próprio ("Mais o público bem que o seu respeita"). Seu desprendimento, sua lealdade, sua coragem são glorificados porque, para salvar o mísero exército português cercado pelos mouros de Tânger, entregou-se aos sarracenos e, por amor à Pátria tornou-se escravo deles que, em seu resgate, exigiam Ceuta. Predominam referências a dados históricos que, expostos com arte, enriquecem o fato, embora adjetive-o "sancto" e declare sua intenção de "altas (divinas) empresas".

Nos três primeiros versos, a sonoridade surda abunda (captivo, sancto, que, tão, empresas, aspirava, que, por, povo) e se associa à ideia à realidade penosa, dura de D. Fernando. Entre o segundo e o terceiro versos, faz-se presente o paralelismo, pois 
ambos os versos são orações subordinadas adjetivas ("Que a tão altas empresas aspirava,/ Que por salvar o povo miserando"), referindo-se a "o sancto irmão Fernando". Esse paralelismo demarca a distância entre o sonhar e o viver. D. Fernando aspirava a altas empresas, mas, para salvar o mísero povo, deu-se como refém. Essa foi sua vida.

O advérbio só ("Só por amor da pátria") reafirma a causa do agir de D. Fernando. Não há outra razão na visão de Camões, embora Pessoa tenha apontado a intervenção divina.

Para glorificar ainda mais o patriotismo de D. Fernando, numa comparação épica, são citados, na estância LIII, Codro (último rei de Atenas que procurou todos os perigos até morrer para salvar sua pátria, já que assim previam os oráculos), Regulo (cônsul romano, prisioneiro em Tunis, contrariou com energia as pretensões cartaginesas, apesar de depender delas a sua liberdade, e voltou a Cartago, onde o trucidaram), Cúrcio (que se precipitou em 360 AC, num abismo existente no meio do Fórum por dizerem os oráculos que tal abismo se fecharia apenas quando a ele se jogasse o que Roma tivesse de mais valioso) e os Décios (Públio Décio, seu filho e seu neto expuseram-se a todos os perigos no intuito de salvar a pátria, lutando respectivamente conta os latinos, os gauleses e os samnitas contra Pirso). Embora todos eles tenham se sacrificado pela pátria heroica e exemplarmente, nenhum deles "fizeram tanto!", foi tão magnânimo, arrojado quanto D. Fernando. Novamente o conceito de heróis portugueses mais bravos do que os da Antiguidade, como anteriormente já se pôde constatar (estância III do canto I).

Camões, novamente, não só revelou a realidade objetiva, mas a superou numa ideia-força que suscita e cria formas superiores de vida. Essa forma superior de vida, no entanto, é mérito pessoal da personagem histórica, o que difere da visão pessoana.

Terceira/ D. Pedro, regente de Portugal

Claro em pensar, e claro no sentir

E claro no querer;

Indifferente ao que há em conseguir

Que seja só obter;

Dúplice dono, sem me dividir,

De dever e de ser -

\section{Canto VIII, estância XXXVII}

Olha cá dous infantes, Pedro e Henrique, Progênie generosa de Joanne:

Aquele faz que a fama ilustre fique D'elle em Germânia, com que a morte engane Este, que ella nos mares o pubrique Por seu descobridor e desengane 
Não me podia a Sorte dar guarida Por não ser eu dos seus:

Assim vivi, assim morri, a vida,

Calmo sob mudos céus,

Fiel à palavra dada e a ideia tida.

Tudo o mais é com Deus!
De ceita a maura vaidade,

Primeiro, entrando as portas da cidade.

O terceiro poema de “As Quinas” é dedicado a D. Pedro, irmão de D.Duarte e D. Henrique. O infante D. Pedro, que posteriormente foi regente de Portugal, era homem culto, traduziu Cícero, Sêneca, Vegácio, além de escrever a Virtuosa Benfeitoria com a intenção de recomendar padrões e normas de conduta à nobreza. Nessa obra expõe seu ponto de vista de que a autoridade dos senhores provém de uma ordenação divina.

O poema pessoano é constituído de dois sextetos. No primeiro deles, alternam-se versos decassílabos heroicos e hexassílabos, com a presença de rima alternada e todas agudas; no segundo, também se alternam versos decassílabos e hexassílabos. A rima nele é alternada, também alternada a rima aguda e grave.

D. Pedro, tido como homem inteligente e viajado, declara-se: "Claro em pensar, e claro no sentir/ E claro no querer;". O termo claro repetido três vezes consecutivamente evidencia a grande objetividade, percepção e entendimento do que pensa, sente e quer; não obstante, no verso seguinte, sobrevém a declaração da ausência desse pensar, sentir e, sobretudo, do querer, destacado em um só verso ("E claro no querer,") porque há indiferença “ao que há de conseguir" que seja só obter, aquilo que for material apenas. Não há, portanto, voluntariedade, desejo, sonho em qualquer conquista, já que, explica-se, "é só obter". D. Pedro declara-se "Duplice dono" e ainda sem se dividir ("sem me dividir"), pois é inteiramente dever e ser, a mesma concepção de D. Duarte. A explosão da sonoridade oclusiva nos três últimos versos ("Que seja só obter; Duplice dono, sem me dividir,/ De dever e de ser-") e a assonância do /e/ no último verso ("De dever e de ser-") dão maior força, intensidade a altissonante declaração real.

As rimas dessa estrofe, como já exposto, são todas agudas. Dão organização rítmica, visto que marcam incisivamente o fim do verso, e consonância à afirmação dada: a clareza do auto-conhecimento do regente português como ser que, embora seja ambicioso apenas de bens espirituais, cumpre o dever de conquistar algo. 
A estrofe que segue tem mudada, nos primeiros versos, a tônica do discurso. Quase que num cochicho, o regente se diz apartado da sorte. A ideia dessa separação se faz mais compreensível com a dupla presença do advérbio não. Se não ocorreu interferência da sorte nem tampouco do céu, que é mudo ("sob mudos céus"), o eu-lírico diz: "Assim vivi, assim morri, a vida,", em verso dividido em três tempos $\left(4^{\mathrm{a}}, 8^{\mathrm{a}}\right.$ e $11^{\mathrm{a}}$ sílabas), o único decassílabo sáfico do poema e, por isso, de leitura mais pausada e marcada. Além disso, pode-se ainda observar, nesse mesmo verso, a repetição do advérbio assim que denota a pouca importância dada à vida que, no singular oxmoro, o eu-poético declara tê-la matado ("assim, morri, a vida,"). A assonância do /i/, a sonoridade do /v/ e a longa duração dos fonemas $/ \mathrm{m} / \mathrm{e} / \mathrm{s} /$ adicionam ao verso melodia e corroboram com a ideia de aceitação de um destino já determinado sem entusiasmo, mas "Calmo sob mudo céus," outro verso em que há a presença alongada do fonema nasal /m/ e a abundância do fonema sibilante /s/.

Os dois últimos versos do poema retomam o tom decidido e forte da primeira estrofe. A presença copiosa de fonemas surdos, além do sonoro /d/, linguodental como o /t/ reforçam a noção do dever assumido como rei e cumprido (a ideia foi clara e, portanto, sua execução aconteceu como o prometido (a palavra dada). Todavia, advém um alerta: "Tudo o mais é com Deus!" O que Deus determinou ao homem foi executado, mas se não foi da melhor maneira, tudo o que não fez bem, é com Deus.

D. Pedro não se declara dependente da proteção divina nem tampouco tão sujeito a Deus como D. Fernando e D. Duarte. D. Pedro diz-se desprovido de Sorte (grafada com maiúscula) e exalta seu eu ("Claro no pensar, e claro no sentir/ E claro no querer"). Acusa a Sorte de não lhe ter dado guarida e declara que, o que está por vir é com Deus, porque, dentro das suas possibilidades humanas, fez tudo quando soube e pôde, mesmo desprovido de sorte.

Se Pessoa dedica todo um poema a D. Pedro, regente de Portugal, Camões apenas meia estrofe, porque aborda D. Pedro e D. Henrique "Progênie generosa de Joanne.", numa mesma estância, a XXXVII do oitavo canto.

A métrica e a rima, como já foi exposto, permanecem a mesma ao longo de toda a obra, sem, no entanto, causar nenhum tipo de monotonia. 
De maneira peculiar e pouco suntuosa, é chamada a atenção para os dois infantes D. Pedro e D. Henrique: “Olha cá dous infantes,". Talvez, Camões os tenha apresentado dessa maneira por não valorizar intensamente nenhum deles. Pedro é o primeiro a ser apresentado, pois é o mais velho, e, portanto, a referência que lhe é feita ocorre através do pronome demonstrativo aquele (“Aquelle faz"). Destaca de D. Pedro o fato de ter enganado a morte (uma prosopopeia) na Alemanha, em luta gloriosa no exército do Imperador Segismundo contra os turcos. ( Apud CAMÕES, s/d, p. 450)

A dedução do menor valor dado aos infantes, embora Camões os tenha alcunhado de "Ínclita Geração" quando os apresenta como filhos de D. Felipe, se justifica, principalmente, pelo comentário negativo feito a respeito de D. Henrique, que procedeu de modo que "ella" [a fama] o apregoe "Por seu descobridor" (descobridor dos mares).

Tantos os feitos de D. Pedro como os de D. Henrique, segundo Camões, são conhecidos através da fama (“Aquelle faz que a fama illustre fique/ D'elle em Germânia, com que a morte engane;/ Este, que Ella nos mares a pubrique") e a fama, na maioria das vezes, não é bem vista pelo autor de Os Lusíadas. No canto IX, nas estâncias XLV e XLVI, na voz do Cupido, por exemplo, a fama faz com que fatos se tornem verdadeiros e influenciem os sentimentos alheios.

A interpretação histórica sob os pontos de vista camoniano e pessoano, portanto, difere. Camões, que revisita toda a História de Portugal conhecida no seu tempo, revela D. Pedro, o regente, apenas como mais uma figura do percurso cuja fama de seu heroísmo o consagrou; Pessoa o traduz como mais uma figura marcada pela desgraça, “protagonista (s) de uma aventura mais mística do que material”. (GARCEZ, 1989, p. 6)

\section{Quarta/ D. João, infante de Portugal}

Não fui alguem . Minha alma estava estreita

Entre tam grandes almas minhas pares,

Inutilmente eleita,

Virgemmente parada;

Porque é do portuguez, par de amplos mares,

Querer, poder só isto:

O inteiro mar, ou a orla desfeita-

O todo, ou o seu nada. 
O poeta dá a voz a D. João, infante de Portugal, irmão de D. Duarte, D. Henrique, D. Pedro e D. Fernando e, portanto, filho de D. João I, o qual declara não ter tido oportunidade ("Não fui alguem") e se justifica pela existência de outros que o abafam com sua grandiosidade. Importante observar que não é sua pessoa diminuída entre pessoas grandes ou grandiosas, mas sua alma entre almas, apenas o que é substância autônoma em relação à materialidade do corpo, "A própria consciência autônoma em relação à materialidade do corpo, "A própria consciência pensante em sua dimensão psicológica, orgânica ou neuronial” (HOUAISS, 2001). A presença do enjambent entre o primeiro e o segundo versos, a assonância do /a/ e do /e/ (Minha alma estava estreita/ Entre tam grandes almas minhas pares"), a sonoridade da oclusiva /t/ na sequência "estava estreita/ entre tam", a presença do primeiro verso decassílabo sáfico e o subsequente heroico despertam-nos, conferem-nos expectativa. Nos dois versos hexassílabos seguintes da quadra, nos é apresentado como se sente a alma estreitada de D. João. É “inutilmente eleita” porque, na concepção da dinastia de Avis, aliás muito bem assinalada na Virtuosa Benfeitoria do infante D. Pedro, a autoridade dos reis, príncipes e senhores é ordenação divina e, se ela é abafada, é inútil, assim como, se não foi posta em prática, está "Virgemmente parada". A rima interna (inutilmente/ virgemmente) aliada ao mesmo ritmo e ao mesmo metro (hexassílabo) reforça o conceito do que não acarreta frutos, da esterilidade, da aridez, da monotonia.

Se a primeira estrofe traz apenas aspectos negativos voltados ao eu-poético ("Não fui alguem", "alma estreita", "Inutilmente eleita", "parado"); a segunda, referindo-se agora aos portugueses, revela o positivo em verso decassílabo heróico, forte, épico, com uma cesura marcada pela vírgula que salienta o aposto "pae de amplos mares". Toda essa positividade é acentuada pela sonoridade das oclusivas: "Porque é do portuguez, pae de amplos mares,/ Querer, poder só isto:” e ainda pela rima interna querer/poder.

A esse povo português que já é "pae de amplos mares", lhe é permitido tudo querer, tudo sonhar, mas apenas lhe interessa, segundo a voz do eu-lírico, obter tudo ou nada, todo o mar ou nenhum mar. A presença do advérbio só não deixa nenhuma outra possibilidade, nenhum outro meio termo, apenas a antítese, que distancia ainda mais, "O todo, ou o seu nada". Mais uma vez a sonoridade vem em auxílio da noção exposta: o 


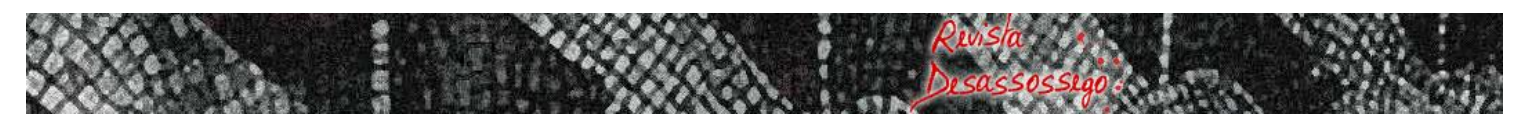

comparecimento das linguodentais /t/(surda) e /d/ (sonora), alia-se à compreensão dos extremos todo ou nada ("O inteiro mar, ou a orla desfeita/ O todo ou o nada.").

Não nos parece sensato desejar tudo ou nada, mas o anseio por ter tudo, mesmo na possibilidade do nada, dá a esse povo motivação, força, determinação para lutar pelo todo.

Em Os Lusíadas não encontramos nenhuma referência ao infante D. João, só está implícito da "ínclita geração", fato explicado, provavelmente, pela pouca importância da sua atuação na História Portuguesa, embora Fernando Pessoa o veja como um dos pilares da constituição da alma lusitana, porque também ele, na sua pequenez ("Não fui alguem", "Minha alma estava estreita"), paradoxalmente, é exaltado.

Louco, sim, louco, porque quis grandeza

Qual a sorte a não dá.

Não coube em mim minha certeza;

Por isso onde o areal está

Ficou meu ser que houve, não o que ha.

Com o que nella ia.

Sem a loucura que é o homem

Mais que a besta sadia,
E vós, ó bem nascida

Da lusitana antigua liberdade

De aumento de pequena christandade, Vós, ó novo tremor da maura lança, Maravilha fatal da nova idade,

Dadas ao mundo por Deus, que tudo o

Pera do mundo a Deus dar parte grande

$$
\text { Canto I - estância VII }
$$

Cadaver addiado que procria?

Vós, tenro e novo ramo florescente

D'ua arvore de Christo mais amada

Que nenhua nascida do Occidente.

Cesárea ou Christianissima chamada,

(Vêde o no vosso escudo, que presente Vos amostra a Victoria já passada, $\mathrm{Na}$ qual vos deu por armas e deixou As que elle pera si na Cruz tomou);

\section{Canto I - estância VIII}

Vós, poderoso rei, cujo alto imperio O sol, logo em nascendo, vê primeiro, Vê-o tambem no meio do hemispherio, E quando desce deixa derradeiro; 


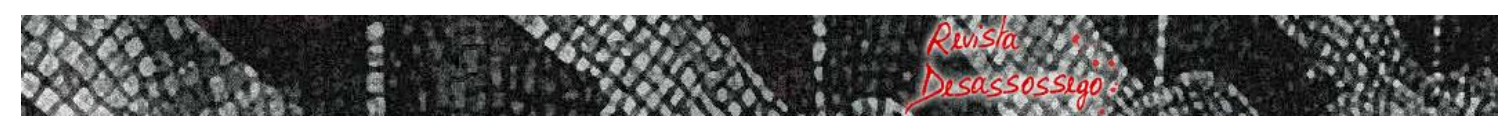

Vós, que esperamos jugo e vutuperio

Do torpe ismaelita cavaleiro,

Do Turco oriental e do Gentio

Que ainda bebe o licor do sancto rio;

$$
\text { Canto I - estância XV }
$$

E em quanto eu estes canto, e a vós não

[posso

Sublime rei, que não me atrevo a tanto, Tomai as redeas vós do reino vosso, Dareis materia a nunca ouvido canto Comecem a sentir o peso grosso (que pelo mundo todo faça espanto) De exercitos e feitos singulares

De Africa as terras e do Oriente os

[mares.

\section{Canto X - estância CLIII}

De Phormião, philosopho elegante, Vereis como Annibal escarnecia, Quando das artes bellicas diante D'elle com larga voz tratava e lia. A disciplina militar prestante Não se aprende, senhor, na phantasie, Sonhando, imaginando ou estudando; Senão vendo, tratando e pelejando.

“D. Sebastião, Rei de Portugal, o último poema de "As Quinas", é formado por dois quintetos cujos versos, quanto ao metro, variam entre decassílabos, hexassílabos e octossílabos ( $1^{\mathrm{a}}$ estrofe: $10,6,8,8,10 ; 2^{\mathrm{a}}$ estrofe: 10, 6, 8, 6, 10). As rimas, em ambas as estrofes, são alternadas e, em seguida, emparelhadas ( $\mathrm{a}$ b a b b). Rimas agudas só são encontradas na primeira estrofe, nos versos 2,4 e 5.

É iniciado por uma afirmação categórica, constituída de sons fortes e oclusivos (“Louco, sim, louco porque quis grandeza/ Qual a sorte a não dá.”), findada por rima aguda e em verso decassílabo.

O homem verdadeiramente humano, para Pessoa, é o descontente, insatisfeito, irracional, que busca a aventura sem freios e, por isso, tido como louco. D. Sebastião diz-se louco porque desejou grandeza (“Qual a sorte não dá”), porque ousou, não fícou 
"Contente com o seu lar,/ Sem que um sonho, no erguer da asa,/ Faça até mais rubra a brasa / Da lareira a abandonar!"7, pois viver assim é o mesmo que ter por vida a sepultura.

O eu-poético vai além e afirma "Não coube em mim minha tristeza"; em outras palavras menos poéticas, não se acomodou satisfeito consigo mesmo, mas lutou para superar as imperfeições, a "certeza" e, por isso mesmo, a conclusão da estrofe: "Por isso onde o areal está/ Ficou meu ser que houve, não o que ha".

Porque buscou a superação de si mesmo, insurgiu-se contra suas limitações, terminou, provavelmente, seus dias prisioneiro em um deserto e nele ficou o "ser que houve", ficou sua metade humana que definha e morre, mas "não o que ha", a metade divina que impele a História.

Nessa primeira estrofe, onde predominam rimas agudas, fica demarcada com firmeza a concepção de vida do Desejado e é, nos versos decassílabos, onde ocorrem as afirmações mais categóricas.

Na segunda estrofe, menos incisiva, mais fluente inclusive pela presença do enjambement no segundo verso, a ideia de loucura é retomada, conceito esse já exposto outras vezes, como no ensaio de 1923: "Loucos são os heróis, loucos são os santos, loucos são os gênios, sem os quais a Humanidade é uma mera espécie animal, cadáveres adiados que procriam”. (Apud MOISÉS, 1996, p. 72)

"Minha loucura, outros que a tomem/ Com o que nella ia". Nesses versos, a presença marcada de encontros vocálicos (loucura, outros, me a, ia) e de sons nasais (minha, me, tomem com, melhor) imprimem mais ainda aos versos continuidade, fluidez de pensamento e de sons para, então, destacar o questionamento arrojado de D. Sebastião: sem a loucura, "que é o homem mais que a besta sadia, cadáver addiado que procria?" Novamente a explosão de oclusivas (loucura, que, que, besta, sadia, cadáver, addiado, procria) vem ao encontro de uma ideia chave: a existência esvaziada de sonhos ambiciosos, a existência apenas satisfeita com suas limitações é a morte em vida, "Cadáver addiado que procria". Embora, nessa estrofe, as rimas sejam graves, tradicionalmente tidas como mais brandas, as rimas no hiato $i a$, cuja sílaba tônica é o $i$

\footnotetext{
${ }^{7}$ Poema "Segundo/ O Quinto Império" da terceira parte de Mensagem, "O Encoberto".
} 
(sadia, procria) revela-se bastante contundente e de acordo com a pergunta feita, que também foi elaborada em verso decassílabo heroico.

Camões, sem quebra do tom épico e mantendo a unidade estrutural, também aborda D. Sebastião, ou melhor, dedica-lhe a epopeia ${ }^{8}$. São treze estâncias dirigidas ao jovem rei de Portugal, das quais destacamos apenas quatro (VI, VII, VIII, XV) por serem as que mais tratam do rei (nas demais, refere-se à qualidade de seus versos e a heróis).

D. Sebastião foi rei com apenas três anos e, com quatorze, assumiu o poder, libertando-se de influências e nomeando novos ministros. A voz poética de Os Lusíadas dirige-lhe a palavra, tratando-o pela segunda pessoa do plural (vós) e elogia-o: "É segurança/ Da lusitana antigua liberdade,”, pois nele está depositada a esperança e a continuidade da descendência de Avis; é "esperança/ De aumento da pequena christandade", conceito medieval de levar a fé através das Cruzadas; é "temor da maura lança (expressiva sinédoque) e "maravilha fatal", destinado por Deus para dominar, mas também a Deus se render. Pela primeira vez, no estudo de estâncias camonianas, a personagem é apontada como agraciada por Deus. Camões, em seus versos, também põe sua esperança em D. Sebastião.

Na estância VII, numa sequência de levantada inspiração, dirige-se ao jovem comarca novamente através do vocativo vós e declara-o "novo ramo florescente/ D'ua arvore de Christo mais amada/ Que nenhua nascida no Occidente (nem mesmo a “Cesárea ou a Christianissima”). Essa metáfora feliz coloca D. Sebastião como ramo novo e florescente, isto é, que já traz marcas de desenvolvimento embora jovem, de crescimento, e descendente de uma família cristã, cujas boas raízes e tronco firme (porque é árvore) o sustentarão. Pede, então, que o rei verifique o escudo, para nele poder encontrar as provas da glória já passada, a batalha de Ourique e as chagas de Cristo. Segundo Chevalier e Gheerbrant, o escudo é "representação do universo, como se o guerreiro a usá-lo opusesse o cosmo ao seu adversário, e como se os golpes desse último atingissem muito além do combatente à sua frente e alcançassem a própria realidade representada nos ornamentos do broquel". (CHEVALIER; GHEERBRANT, 1982, escudo) Se o rei é solicitado a verificar o escudo, portanto, é para que não tema,

\footnotetext{
${ }^{8}$ Camões desejava o reconhecimento de sua arte por parte de D. Sebastião, para dele receber uma tença.
} 
pois nele está a sua defesa. O pedido é colocado entre parênteses, como que baixando a voz respeitosamente, ao solicitar algo. Esses versos transmitem uma vez mais expectativa em D. Sebastião, o consumador de um novo império.

A estrofe seguinte, também iniciada pelo vocativo vós, D. Sebastião é exaltado através de outra metáfora: para ele, o sol está sempre voltado, seja no amanhecer ou no ocaso. A expressão adverbial "logo em nascendo", colocada entre vírgulas no meio da oração, destaca quão cedo esse sol vem ao encontro do jovem monarca. Novamente o rei é chamado (vós) e, sobre ele, é deposta uma grande esperança: a vitória sobre gentios e bárbaros ("o torpe ismaelita cavaleiro", uma sinédoque, pois, na verdade, são os ismaelitas).

Nessa mesma estância, ainda, chama-nos a atenção a anáfora "Do torpe.../ Do turco...”. Os que devem ser combatidos da mesma forma estão em versos iniciados de forma semelhante.

Na estância XV, depois de uma preterição, pois o eu-poético declara não se atrever cantar seu rei, mas o faz, mais do que um elogio e expectativa, há um desafio: "Tomai as rédeas vós do reino vosso" e a profecia: "Dareis matéria a nunca ouvido canto" através dos feitos espantosos dos seus soldados e exércitos.

A anáfora, nessa estrofe, se faz presente realçando o jogo rítmico: "De exércitos e feitos singulares/ De África as terras e do Oriente os mares". A sinestesia também ("peso grosso") faz com que, na transferência de sentido, o peso trazido pelos soldados nas terras africanas e nos mares orientais seja ainda mais sentido.

Ainda no canto X, estância CLIII, a voz épica fala diretamente a D. Sebastião, mas antes, dando mais peso ao seu conselho, faz uso de figuras do Mundo Antigo (Annibal, famoso general cartaginês, escarnecendo do elegante filósofo grego, Phormião, quando, diante dele, lia tratados sobre a arte bélica). Interessante observar que, mesmo querendo apontar uma falha no procedimento real, o eu-lírico compara o rei não só a um filósofo, mas a um filósofo elegante.

Nesses versos não há elogio, expectativa ou profecia, apenas um alerta (muito sonoro, aliás, em decorrência das rimas internas), que revela o conhecimento da voz poética das limitações reais. Talvez já a previsão inconsciente do "desmoronamento 
progressivo de que Camões entendia que deveria ter sido o Quinto império" (GARCEZ, 1989, p. 3).

Nas estâncias do primeiro canto, Camões coloca em D. Sebastião, que é dom de Deus, a esperança de grandes feitos que hão de vir; em "As Quinas" o jovem monarca português é o desbravador, o conquistador intrépido e valoroso. Ambos, Camões e Pessoa, confiam em D. Sebastião e esperam nele, mas o poeta do Orpheu já conhecia a terrível derrota do governante e, ainda assim, ou melhor, por isso mesmo ${ }^{9}$, nele espera, enquanto Camões, porque não conhece o futuro, apenas crê nele.

Na estância CLIII do décimo canto, na epopeia renascentista indagadora de fenômenos e de consciência crítica, D. Sebastião é apresentado como homem de pouca ação, o que não seria concebível no poema épico pessoano, já que lhe basta que o jovem rei tenha sido exemplarmente marcado pela desgraça para ser glorificado.

\section{Conclusão}

Após o estudo dos poemas de "As Quinas" e das estâncias camonianas que abordam as mesmas personagens históricas, pudemos concluir sobre algumas identidades e várias diferenças.

A maior distinção que se pode fazer entre as duas obras épicas portuguesas diz respeito à finalidade de cada uma. As demais diferenças são decorrentes do objetivo buscado numa e outra.

Camões celebra a viagem de Vasco da Gama às Índias e a história pátria, mantendo identidade com o Cristianismo, e registra, além da realidade histórica, a astronomia, as ciências da natureza, a geografia, a etnografia no intuito de fixar para a posterioridade as grandes façanhas de seus heróis. Eles lutaram contra obstáculos que impediam a nação de ser um dos maiores agentes da civilização do mundo, lutaram pelo cumprimento da missão que a situação geográfica lhes proporcionava, lutaram pela hegemonia do Homem no Universo. Camões não se eximiu, entretanto, de registrar a crise intelectual advinda das navegações e das descobertas, de revelar sua consciência

\footnotetext{
9 "Se o povo Português, em D. Sebastião, teve de passar pelo seu maior "desastre", teve de conhecer a maior "desgraça" e "vileza", segundo a lógica não humana desta História, ele tem agora todos os motivos de esperança num período de glorificação e de grandeza, ele tem todas as credenciais para ser "ungido" com um destino glorioso. Ao "desastre” maior deverá corresponder uma glorificação maior". (GARCEZ, 1989, p. 7)
} 
crítica do conhecimento, de censurar a inquietação que suscita, mas também sacrifica. Sem dúvida, Os Lusíadas constituem um relato de glória, a glória do povo lusitano nas navegações, nas conquistas, na expansão do mar, mas também memorial de um declínio.

Fernando Pessoa, em “As Quinas”, revela uma concepção mais personalizada da História, pois os grandes acontecimentos que demarcam o destino da nação portuguesa são determinados por atos isolados de apenas algumas personagens. Além disso, quando a História Portuguesa é revista na fase anterior a D. Sebastião, oferece-nos uma visão diferenciada à que já nos tinha sido apresentada por Camões: a interpretação de que, para fazê-la, para tê-la foi necessária a dor, a desgraça, o fracasso. Mensagem não festeja o Portugal passado, mas aponta para o futuro, revela a esperança do que poderá vir a ser. Um vez derrotado o país, tem agora todos os motivos para um momento futuro de glorificação e grandeza. O que foi humilhado, será exaltado.

Tendo em vista esse foco, o da diferença, verificamos que, nos cinco poemas extraídos de "As Quinas", não há distinção de tratamento dos reis e infantes. Todos eles são mitificados, todos são marcados pela desgraça. São, por uma razão ou outra, mártires e, por isso mesmo, tocados por Deus, guiados pela mão divina e, portanto, vencedores. Em Camões, nas estâncias aqui citadas e estudadas, é percorrida toda a genealogia dos reis cronologicamente. Ao fazê-lo, detém-se em fatos históricos, exaltando-os em comparações com grandes vultos da história e da mitologia, mas também os apresenta até mesmo com certa indiferença (como nos versos dedicados a D. Pedro e a D. Henrique), quando os julga menores.

Os heróis da pseudo épica pessoana não são apresentados cronologicamente, como ocorre em Os Lusíadas, fato apontado por vários estudiosos do poeta que afirmam ser a negação do tempo uma marca bastante presente na sua poesia ${ }^{10}$. Pessoa selecionou acontecimentos, reis que considerou decisivos segundo determinada analogia e compôs “As Quinas". No momento da batalha de Alcácer Quibir, a narrativa é interrompida ${ }^{11}$. É o momento desastroso, marcado pela dor e, como tal, dará nascimento a um novo

\footnotetext{
10 "é no sentimento originário da sua [do tempo] irrealidade que se gera toda a poesia de Pessoa". In: LOURENÇO, 1999, p. 65.

${ }^{11}$ Camões também interrompe a História no reinado de D. Sebastião, mas porque foi o período que vivenciou.
} 
tempo. Não importa apenas reinterpretar a História portuguesa através da intervenção divina, reinterpretá-la como cenário para algo que está por vir.

A questão das vozes em Os Lusíadas e Mensagem também reflete a interpretação de Portugal feita por cada um dos seus autores. Em "As Quinas", que representam a essência religiosa de Portugal, há uma voz diferente para cada composição, a voz da figura histórica anunciada no título que profere seu monólogo, que fala por si sem a interferência de um observador de fora; Os Lusíadas são saga de um povo narrada por uma única persona poética que se confunde com a imagem do próprio Camões

Ainda por terem sido escritos em épocas tão distintas, 400 anos os separa, as duas obras apresentam formas diferentes de épocas diferentes. Os poemas estudados em Os Lusíadas mostraram sempre rigor na forma, como regulamentam os preceitos quinhentistas, e uniformidade na disposição das rimas, como já demonstrado. Os poemas de "As Quinas", embora tragam certo rigor, ele não é o mesmo em todos os poemas. Em Os Lusíadas nos encanta o tom épico que percorre toda a obra e o conhecimento extraordinário do autor das mais diversas áreas do conhecimento, mas, sobretudo, da História e da Mitologia. Em Mensagem, nos emociona a arquitetura do texto, a maneira como foi concebido, além é claro, da arte de cada poema.

Quanto às semelhanças, destacamos a concepção nacionalista exaltada nas duas obras. Embora Camões revele sua decepção em determinadas passagens, engrandece a força, a coragem, a determinação do seu povo; Pessoa agiganta os feitos, a determinação dos heróis da História Portuguesa tocados pela graça divina.

Nas epopeias clássicas, como em Os Lusíadas, depois da proposição e invocação, vem o plano divino, representado pelo concílio dos deuses, onde são discutidos os desígnios humanos. "As Quinas" vêm depois de uma abertura do poema, apresentando a Europa e Portugal na sua posição privilegiada, como expoentes da História do mundo, isto é, o plano humano. Depois de conhecido o plano humano, vêm "As Quinas", que trazem o plano divino nas suas relações com o homem Outra semelhança, portanto, agora na formação do poema.

A aproximação entre Os Lusíadas e Mensagem é inevitável, mas, se pudemos apontar mais diferenças que semelhanças, não há incoerência, pois há ainda uma grande 
igualdade a ser apresentada que une a produção épica dos dois maiores poetas portugueses: levaram a língua e a história lusitana do quintal português para o mundo.

\section{Referências bibliográficas:}

BAKHTIN, Mikhail. Estética da criação verbal. São Paulo: Martins Fontes, 1981.

CAMÕES, Luis Vaz de. Os Lusíadas. Organização de Emanuel Paulo Ramos. 7.ed. Porto: Porto. s/d.

A Chave dos Lusíadas. Prefácio, paráfrase de José Agostinho. 6.ed. Porto: Livraria Figueirinhas, s/d.

CARVALHO, Joaquim Barradas de. O Renascimento português em busca de sua especificidade. Lisboa: Imprensa Nacional - Casa da Moeda, 1980.

CARVALHO, João Soares. História da Literatura Portuguesa, vol. 2 - Renascimento e Maneirismo. Lisboa: Alfa, 2001.

CHEVAlIER, Jean; GHEERBRANT, Alain. Dicionário de Símbolos. 18.ed. Rio de Janeiro: José Olympio, 1982.

CIDADE. Hernani. A Literatura Portuguesa e a Expansão Ultramarina. As idéias - os factos - as formas de arte, vol. 1, séc. XV e XVI. 2.ed. Coimbra: Armênio Amado, 1963.

COELHO, Jacinto de Prado. Diversidade e Unidade em Fernando Pessoa. 5.ed., 1.ed. brasileira. São Paulo: Verbo, 1974.

CRESPO, Angel. Estudos sobre Fernando Pessoa. Tradução de José Bento. 5.ed., 1.ed. brasileira. São Paulo: Verbo, 1974.

ELIOT, T. S. Ensaios. São Paulo: Art, 1974.

FRANCHETTI, Paulo; GARCEZ, Maria Helena Nery. A Viagem de Vasco da Gama na Virada do Século. In: Estudos Portugueses e Africanos. Campinas: UNICAMP, n 22 , julho-dezembro, 1993, p. 51-64.

GAGLIARDI, Caio. A Pátria de Sonho Portuguesa. In: PESSOA, Fernando. Mensagem. Organização de Caio Gagliardi. São Paulo: Hedra, 2007, p. 9-29.

GARCEZ, Maria Helena Nery. Uma lírica nunca dantes percebida. In: Poemas Completos de Alberto Caeiro. São Paulo: Nacional e Lazuli, 2007, p. 7-16. 


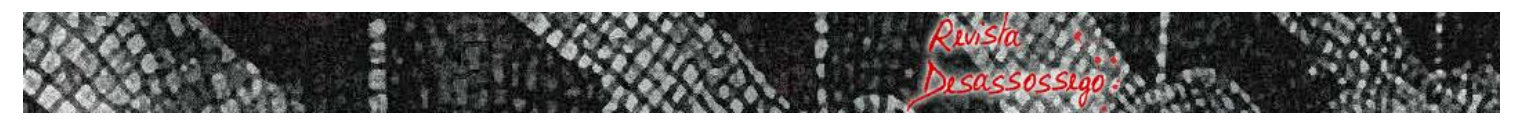

Mensagem: Profissão de Fé Poética. In: Estudos Portugueses e Africanos. Campinas, n²5/26, UNICAMP, 1995, p. 159-169.

. Motivos das Navegações na Poesia Portuguesa do século XX: Antônio Gedeão.

In: Actas do $4^{o}$ Congresso Internacional de Lusitanistas. Lisboa/Porto/Coimbra: LIDEL, 1995, p. 491-198.

Do Desconcerto e do Concerto Mundo em Mensagem. In: Trilhas em Fernando Pessoa e Mário de Sá Carneiro. São Paulo: Moraes, Edusp, 1989.

LANGLOIS, José Miguel Ibañez. La Creation Poética. Madrid: Realp, 1964.

LOURENÇO, Eduardo. Mitologia da Saudade. São Paulo: Companhia das Letras, 1999.

PAREYSON, Luigi. Os Problemas da Estética. Tradução de Maria Helena Nery Garcez. São Paulo: Martins Fontes, 2091.

PESSOA, Fernando. A Nova Poesia Portuguesa Sociologicamente Considerada. In: PESSOA, Fernando. Obras em Prosa. Organização e nota de Cleonice Berardinelli. 2.ed. Rio de Janeiro: Nova Aguilar, 1976, p. 361-378.

Mensagem. In: Obra Poética. Organização e notas de Maria Aliete Galhoz. $4^{a}$ reimpressão da 9.ed. Rio de Janeiro: Nova Aguilar, 1986, p. 5-23.

SARAIVA, Antonio José; LOPES, Oscar. História da Literatura Portuguesa. 2.ed. Porto: Porto, s/d.

SEABRA, José Augusto. O Heterotexto Pessoano. São Paulo: Perspectiva, 1988.

TREVISAM, Armindo. A Poesia. Uma Iniciação à Leitura Poética. Porto Alegre: Uniprom, 2000. 